\title{
1 Microplastic in the stomachs of open-ocean and deep-sea fishes of the North-East Atlantic
}

João M. Pereira ${ }^{1}$, Yasmina Rodríguez ${ }^{1}$, Sandra Blasco-Monleon ${ }^{1}$, Adam Porter ${ }^{2}$, Ceri Lewis²,

5 Christopher K. Pham ${ }^{1 *}$

6

${ }^{1} I M A R / O K E A N O S$ - Universidade dos Açores, Horta, Portugal

$8 \quad{ }^{2}$ College of Life and Environmental Sciences: Biosciences, Geoffrey Pope Building, University

9 of Exeter, Stocker Road, Exeter EX4 4QD, United Kingdom.

*corresponding author: christopher.k.pham@uac.pt

\section{Abstract}

The presence of microplastic in marine fishes has been well documented but few studies have directly examined differences between fishes occupying contrasting environmental compartments. In the present study, we investigated the gut contents of 390 fishes belonging to three pelagic (blue jack mackerel, chub mackerel, skipjack tuna) and two deep-sea species (blackbelly rosefish, blackspot seabream) from the Azores archipelago, North-East Atlantic for microplastic contamination. Our results revealed that pelagic species had significantly more microplastic than the deep-water species. In all of the species studied, fragments were the most common plastic shape recovered and we found a significant difference in the type of polymer between the pelagic and deep-water species. In deep-sea fish we found almost exclusively polypropylene, whereas in the pelagic fish, polyethylene was the most abundant polymer type. Overall, the proportion of fish containing plastic items varied across our study species from $3.7 \%$ to $16.7 \%$ of individuals sampled, and the average abundance of plastic items ranged from 0.04 to 0.22 per individual (the maximum was 4 items recovered in one stomach). Despite the proximity of the Azores archipelago to the North Atlantic subtropical gyre, a region of elevated plastic abundance, the proportion of individuals containing plastic (9.49\%) were comparable with data reported elsewhere.

Capsule: The quantities of microplastic in fish species of the Azores archipelago was higher for pelagic than for deep-sea fishes while the overall proportion of occurrence was comparable to levels reported elsewhere.

\section{Keywords}




\section{Introduction}

Plastic pollution has been identified as one of the major environmental problems currently facing global oceans and marine biota. Plastic items are now commonly observed from shallow coastal areas (Browne et al., 2011) down to the deep-sea floor (Pham et al., 2014; Chiba et al., 2018) and from the Arctic (Zarfl and Matthies, 2010) and Antarctic (Barnes et al., 2009) to the tropics (Do Sul et al., 2014). Despite their wide distribution throughout the marine realm, plastics have been shown to accumulate in certain areas. It is now well established that floating plastic tends to accumulate in oceanic gyres (Law et al., 2010; Ter Halle et al., 2017) as well as sinking to the sea floor (Woodall et al., 2015; Koelmans et al., 2018; Everaert et al., 2018). Ingestion of plastic items has also been reported throughout the marine food chain, from zooplankton up to large baleen whales (Gall and Thompson, 2015; Sun et al., 2017).

Plastics are exceptionally spatially and temporally heterogeneous varying by orders of magnitude within small changes in time or space (Law et al., 2014). Accordingly, a wide variety of fish species $(475)$ are known to ingest plastic items with high variability in the number of individuals containing plastic particles and individual uptake between species, geographic location, habitat and trophic level (Markic et al., 2019). In the seas surrounding populated areas or in accumulation zones (e.g. subtropical gyres) the number of fish containing plastic for any given species has been generally higher (Lusher et al., 2013; Bellas et al., 2016; Naidoo et al., 2016; Peters et al., 2017; Güven et al., 2017; Tanaka and Takada, 2017; Herrera et al., 2019) compared to more remote environments (Annastasopoulo et al., 2013; Foekema et al., 2013; Cannon et al., 2016; Murphy et al., 2017).

Plastics are not just heterogeneously distributed on the surface. When plastics enter the marine environment, some sink straight away and others become fouled or entrained in marine snow and subsequently sink creating a vertical distribution of this material (Galloway et al., 2017; Porter et al., 2018). A number of studies show that fishes occupying different oceanic zones (benthic, pelagic etc.) have reported higher numbers of plastic particles per individual for pelagic species (Rummel et al., 2016; Anastasopoulou et al., 2018), while others found that demersal species had a higher ingestion rate (Kühn et al., 2019) further evidencing the spatiotemporal heterogeneity of plastics in the water column depending on the region. Polymer type is an important factor in this vertical distribution and differences between compartments have been shown to exist in pelagic and benthic species but also within environmental samples (Munari et al., 2017; Porter et al., 2018; Scott et al., 2019). Lighter polymers (e.g. polyethylene) are typically more often found in pelagic species and denser polymers (e.g. polyethylene terephthalate and polyvinylchloride) are more common in benthic fish (Bray et al., 2019).

The Azores is an oceanic archipelago located in the middle of the North Atlantic Ocean that functions as an essential habitat for a variety of marine life, including cetaceans ( $>25$ species), seabirds, sea turtles, oceanic elasmobranchs, and other large pelagic fishes that come to the 
archipelago to feed, mate, or to give birth (Monteiro et al., 1996; Bolten, 2003; Silva et al., 2014; Sobral and Afonso, 2014; Vandeperre et al., 2016; Das and Afonso, 2017). On the seafloor, the numerous seamounts, island slopes and shelves host a high diversity of deep-water corals and sponges that are key components of deep benthic communities, providing habitats for a large variety of organisms (Braga-Henriques et al. 2013; Pham et al., 2015).

The Azores are located at the edge of the North Atlantic subtropical gyre (NASG), within which concentrations of large microplastic (items $1-5 \mathrm{~mm}$ ) have been reported to reach 250000 items $/ \mathrm{km}^{2}$ and up to 7000000 items $/ \mathrm{km}^{2}$ for small microplastic (items $<1 \mathrm{~mm}$ ) (Ter Halle et al., 2017). Within Azorean waters, significant concentrations of plastic items have been recorded floating at the sea surface (Chambault et al. 2018), on the seafloor (Pham et al. 2013a; Rodríguez and Pham, 2017) or found accumulating on several beaches across the archipelago (Ríos et al., 2018, Pham et al., 2020) and also in the gastrointestinal tract of sea turtles (Pham et al., 2017). It is this co-occurrence of both high biodiversity and high plastic abundance that make the Azores a highly relevant location to be addressing questions regarding the biological uptake of plastics, yet the risk of this emergent pollution issue for local biodiversity has not been fully assessed.

This study aims to assess plastic contamination in five different fish species of high commercial interest in the Azores (blackbelly rosefish, Helicolenus dactylopterus; blue jack mackerel, Trachurus picturatus; chub mackerel, Scomber colias; blackspot seabream, Pagellus bogaraveo and, skipjack tuna, Katsuwonus pelamis) occupying both the pelagic and benthic zones. We hypothesise that given the relative proximity to the North Atlantic Subtropical Gyre that our fishes sampled will have an elevated plastic load than other studies taken from the open ocean situated away from major accumulation zones. We also test the null hypothesis that the quantity of plastic will not differ between pelagic and benthic fishes, since to date, there are conflicting results in the literature. Furthermore, we hypothesise that larger fishes will have ingested more particles due to their increased mouth gape and ability to ingest larger prey leading to accidental ingestion and trophic transfer.

The blackbelly rosefish, is a carnivorous species that feeds mainly on benthic crustaceans and fish (Neves et al., 2012), with a bathy-demersal distribution ranging between 200 and $800 \mathrm{~m}$ (Massuití et al., 2001). The blackspot seabream is an omnivorous species that feeds mostly on benthic crustaceans, molluscs, worms and small fish (Morato et al., 2001), this bentho-pelagic species can be found at depths up to $800 \mathrm{~m}$ (Menezes et al., 2006). The blue jack mackerel, feeds mostly on small crustaceans and has a bentho-pelagic distribution between the surface down to $\sim 370 \mathrm{~m}$ deep (Menezes et al., 2006). The chub mackerel feeds on small zooplankton and small fish (Castro, 1993; Collette and Nauen, 1983), with a pelagic-neritic distribution and can be found at the surface down to $\sim 300 \mathrm{~m}$ deep. Finally, the skipjack tuna, that feeds on cephalopods, fish, molluscs and crustaceans (Collette and Nauen, 1983), is a top predator species characterized for its pelagic-oceanic distribution from the surface down to $\sim 260 \mathrm{~m}$ deep. 


\section{Material and Methods}

\section{$112 \quad$ Species selection and sample collection}

113 A total of 390 individuals belonging to five different species (blackbelly rosefish: $n=54$; blue jack

114 mackerel: $n=117$; chub mackerel: $n=114$; blackspot seabream: $n=55$; skipjack tuna: $n=50$ ) were

115 analysed (Table 1). All fishes were caught within Azorean waters through local fisheries by hook

116 and line, which reduces potential biases such as net feeding. Four species (blackbelly rosefish,

117 blue jack mackerel, chub mackerel, blackspot seabream) were directly purchased whole from

118 fisherman at Horta Harbour (38 31'59 N; -28 37’59 W), Faial Island between 2015 and 2018.

119 Skipjack tuna were collected from the canning factory in Pico Island in summer 2017.

120 In the laboratory, each whole individual was measured and weighed. Length of individuals

121 was obtained as the straight distance from the tip of the longest jaw with mouth closed to the tip

122 of the longest caudal lobe pinched together, as described by Miller and Lea (1972). Each fish was

123 then dissected and its stomach was carefully extracted and weighed under clean laboratory

124 conditions. The entire stomachs were stored in new zip-lock bags and frozen at $-20 \mathrm{C}^{\mathrm{o}}$ for

125 subsequent analysis. To prevent potential contamination, the bags were thoroughly washed with

$12620 \mu \mathrm{m}$ pre-filtered deionized water. All species with everted stomachs were excluded from the

127 analysis to avoid including individuals who potentially lost their plastic content. Special attention

128 was taken to select individuals belonging to a narrow size range for each species in order to

129 minimize a possible size effect on plastic presence in stomach content (Table 1). Additionally,

130 we further subdivided chub mackerels and blue jack mackerels into different size categories: small

131 (S; 14.5 to $21.5 \mathrm{~cm})$ and large $(\mathrm{L} ; 21.6-36 \mathrm{~cm})$ - to investigate a potential effect of fish size on

132 plastic content in the stomachs that could be related to differences in diets or habitat use.

133

134

135

136

137

138

139

140

141

142

143

144

145

146

\section{Sample processing}

Samples were analysed using a two-step method (visual sorting and subsequent digestion) to allow the results to be compared with studies that only use visual sorting $(>1 \mathrm{~mm})$ and studies that look at smaller items, as suggested by Lusher et al. (2017).

The exterior of each stomach was thoroughly washed with $20 \mu \mathrm{m}$ pre-filtered deionized water prior to opening in order to remove any possible microfiber contamination present on the outer layer of the stomach to ensure not contamination was present from excision of stomach or storage in zip lock bags. Fish stomachs were cut open vertically from top to bottom, ensuring the contents stayed in the stomach. The contents of each stomach were carefully visualised under a stereo microscope, with 6.4x magnification, for presence of plastic items $(>1 \mathrm{~mm})$. Potential items were extracted from the stomach content with pre-rinsed tweezers and kept in a small petri dish for subsequent measurement and photography. In addition, the fullness of each stomach was scored on a scale from 0 (empty) to 5 (full). During visual sorting, a single blank filter for each stomach 
was left open to the air for airborne contamination control. Full details of the size range and stomach weights of the fish sampled are presented in Table 1.

After visual sorting, the entire stomachs were digested with $10 \% \mathrm{KOH}$ at $40 \mathrm{C}^{\circ}$ for at least 72 hours, as recommended by Karami et al. (2017) to ensure complete digestion but also to limit the degradation of certain plastic polymers. Dehaut et al. (2016), found microplastic recovery rate of $100 \%$ using this method, for most polymers, with the exception of polycarbonate (PC) and PET. The digested solution was sequentially filtered through a pre-rinsed $50 \mu \mathrm{m}$ mesh and $1 \mu \mathrm{m}$ pore size glass fibre filters. During this phase a blank filter was left open inside the fume-hood to control for airborne contamination and changed every five samples. A blank filtration with $20 \mu \mathrm{m}$ pre-filtered deionized water was also performed every 5 samples. All filters were then analysed under a Leica binocular MZ16FA coupled with a MC 190 Leica camera. Every potential plastic item $(>20 \mu \mathrm{m})$ was photographed and the maximum calliper length measured using the Leica LAS V4.12 software. A blank filter for each sample was left open to the air again to control contamination, and was checked immediately after completing the visualisation of the samples. Potential plastic items were classified into small microplastic $(20 \mu \mathrm{m}$ to $<1 \mathrm{~mm})$, large microplastic (1-5 mm), mesoplastics $(5-25 \mathrm{~mm})$ and all items larger than $25 \mathrm{~mm}$ were grouped as macroplastics. Shape was classified according to Kühn et al., (2019) into thread, fragments and fibres (fibres are dust like particles from clothing whereas threads are larger strands from polyfilament nets or monofilament line). The colour of each item was also recorded in the following colour groups: blue, black, brown, green, orange, red, transparent, yellow and white. All items recovered were treated as potential plastic and further analysed using $\mu$-Fourier transform infrared spectroscopy ( $\mu$ FTIR) for result validation and polymer identification. For small items $(<1 \mathrm{~mm})$ FTIR spectra were obtained using a Perkin-Elmer Spotlight $400 \mu$ FT-IR Imaging System operating in reflectance mode. Larger items $(>1 \mathrm{~mm})$ were analysed with a Perkin-Elmer Frontier spectrometer, using a universal diamond - ATR attachment. Spectra were processed with Perkin-Elmer's Spectrum ${ }^{\mathrm{TM}} 10$ software enabling data normalisation and base-line correction. Polymer identification was made by comparing scanned spectra with commercially available spectral libraries. Only matches that were $\geq 70 \%$ were considered as valid identification. Out of all potential plastic items initially recovered, $68 \%(n=165$ items) of potential plastic items were analysed directly using $\mu$-FTIR. Because $\mu$-FTIR analysis is a time-consuming method, if identical particles were found repeatedly in one or several individuals of the same species, its identity would be inferred after at least 5 of those particles were analysed. Therefore, the remaining potential plastic items $(32 \%)$ were inferred based on the $\mu$-FTIR results.

\section{$\underline{\mathrm{QA} / \mathrm{QC} \text { procedures }}$}

All materials used during the laboratory analysis were washed with $20 \mu \mathrm{m}$ pre-filtered water and checked under a stereomicroscope for the presence of microfibers before being used. In each 
separate phase of the analysis, a blank filter paper was left exposed to the air whenever the samples were treated as described above. This measure was taken to evaluate the contamination through atmospheric deposition of microfibres in the laboratory and the results were corrected accordingly. Each microfibre found in the control filters was photographed and compared with the microfibres found in the samples. Any particle identical to a fibre from the control filters was excluded from the results. Additionally, some blanks were left in the laboratory next to entrance zones as extra safety control. Fibres present in those filters were also cross-checked with the microfibres identified in the stomachs and excluded from the results in case of similarity. Lab coat and nitrile gloves were used during all laboratory phases. The final data presented have therefore been corrected by removing any particle that returned a $<70 \%$ match through spectral analyses, and have had any item matching the microfibres found in the corresponding blanks (22 microfibres in 9 samples) removed. Whilst blue cellulosic fibres were present in some of the samples they are not included in this analysis (they did not fit the required spectral analysis match).

\section{$\underline{\text { Statistical analysis }}$}

The proportion of fish containing plastic particles, plastic abundance and plastic load were calculated for each species and size groups following guidelines in Provencher et al. (2017). Only the corrected data was used in the analysis. Plastic abundance was calculated as the average number of plastic items found in all fish sampled (whether they had plastics present or not), while plastic load reports the average number of plastics items in the guts of only fishes that did contain plastics. This is commonly misreported in the literature and can lead to difficult data comparisons. Spearman's correlation test was used to assess the relation between fullness degree and abundance and load of plastics within the fish. Differences in plastic content (abundance and load) between species, size classes and environmental compartment (pelagic vs benthic), were evaluated with Kruskal-Wallis and Dunn's tests due to non-normal distributions. Differences in shape, colour and polymer composition of the plastics present in the stomachs between habitats and species were tested for significance using ANOSIM (Analysis of similarity). Bray-Curtis similarity was calculated on $\log (\mathrm{x}+1)$ transformed data and a similarity percentage analysis (SIMPER) was applied to identify the discriminating feature of the dissimilarities and similarities between habitats and species. The level of significance used in the statistical tests was $p=0.05$. All statistical analyses were performed using the computing environment R (R Core Team, 2019).

\section{Results}

A total of 3 suspected macroplastic items, 5 suspected mesoplastic items and 234 suspected microplastic items $(<5 \mathrm{~mm})$ were initially identified from the first sorting phase. Following $\mu$ - 
FTIR analysis, only 52 out of the initial 242 items were confirmed as true plastic polymers ( 7 items $>5 \mathrm{~mm}$ and 45 items $<5 \mathrm{~mm}$ ).

Stomach fullness was highly variable between species with $47 \%$ of individuals of blackbelly rosefish having empty stomachs while none of the blackspot seabream had empty stomachs.

From the 390 fish sampled across all species, a total of 37 (i.e. 9.49\%) of them contained plastic debris in their stomachs. The number of plastic items recovered per individual ranged from 0 to 4 with an average of $0.13 \pm 0.02$ items ( $\pm \mathrm{SE}$ ) per fish. For the individuals which contained plastic, the average plastic load per individual was $1.4 \pm 0.04( \pm \mathrm{SE})$ across all species.

We found a higher proportion of plastics present in the pelagic fishes sampled $(11.7 \%$ of individuals contained plastic) compared to benthic fishes sampled (3.7\% of individuals contained plastic) (Fig. 1). Plastic abundance in pelagic fish was significantly higher compared to benthic fishes (Fig. 1, Chi square $=5.95 ; \mathrm{p}=0.01 ; \mathrm{df}=1$ ). For pelagic species, the average abundance of items per fish was $0.17 \pm 0.03( \pm \mathrm{SE})$. A total of 47 plastic items were recovered from 33 pelagic fishes, which represents an average plastic load of $1.4 \pm 0.05( \pm \mathrm{SE})$. For the benthic species, the average abundance of items present per fish was $0.05 \pm 0.02( \pm \mathrm{SE})$. A total of 5 plastic items were recovered from 4 fishes, which represents an average plastic load of $1.2 \pm 0.05$ ( $\pm \mathrm{SE})$ items per fish.

In the two pelagic species (chub mackerel and blue jack mackerel) for which we tested for a size dependant effect, no significant differences were found in the abundance of plastic items between large and small individuals (Chi square $=0.14 ; \mathrm{p}=0.71 ; \mathrm{df}=1$ and Chi square $=0.56 ; \mathrm{p}=$ $0.45 ; \mathrm{df}=1$, respectively). Therefore, results for those two species are reported without separating the size classes. Plastic content was highest for chub mackerel with $16.7 \%$ of individuals sampled containing plastic (Fig. 1), and an average abundance of $0.22 \pm 0.06( \pm$ SE) items per fish (Table 2). For this species, a total of 25 items were recovered in the stomach contents of 19 individuals, which represents an average plastic load of $1.3 \pm 0.1( \pm \mathrm{SE})$ items per individual and a range from 1 to 4 items per fish. For blue jack mackerel $7.7 \%$ of individuals sampled contained plastic (Fig. 1 ), and this species had an average abundance of $0.12 \pm 0.05$ ( $\pm \mathrm{SE}$ ) plastic items per fish (Table 2). A total of 14 items were recovered in 9 individuals, with an average plastic load of $1.6 \pm 0.1$ ( \pm SE) items per individual, ranging from 1 to 4 items per fish. The final pelagic species, the skipjack tuna, had a contamination rate of $10.0 \%$ (Fig. 1), and an average of $0.16 \pm 0.08$ ( \pm SE) plastic items were recovered per fish (Table 2). A total of 8 plastic items were recovered in the stomach content of 5 individuals, the average plastic load was $1.6 \pm 0.1( \pm \mathrm{SE})$ items per fish, with a maximum of 3 plastic items recovered per fish for this species.

In the benthic fishes, we found that $3.7 \%$ of blackbelly rosefish individuals sampled contained plastic (Fig. 1), and an average abundance of $0.06 \pm 0.04$ ( \pm SE) items per fish (Table 2). A total of 3 plastic items were recovered in 2 individuals corresponding to an average plastic load of 1.5 \pm 0.1 ( $\pm \mathrm{SE}$ ), with a maximum of 2 plastic items per fish (Table 2$)$. In the case of the blackspot 
seabream, 3.6\% of individuals contained plastic and the average abundance of items was $0.04 \pm$ $0.03( \pm \mathrm{SE}$ ) per fish (Table 2). A total of 2 plastic items were found in 2 fishes, corresponding to an average plastic load of 1 plastic item per fish (Table 2).

Plastic fragments $(n=34)$ were the most frequent shape of plastic items recovered, contributing to $65 \%$ of the total number of items. Plastic fragments were found in all five species sampled. Fibres $(n=12)$ comprised $23 \%$ of the items and thread-like items $(n=6)$ made up the remaining 12\% (Fig. 2). Fibres were found in all species with the exception of the blackspot seabream whereas thread-like items were only found in two pelagic species, skipjack tuna and chub mackerel (Fig. 2). Results from ANOSIM showed no significant differences in the shape of the items present in the stomachs between pelagic and benthic fishes (1-way ANOSIM; Global R= $0.09 ; \mathrm{p}=0.78$ ) and between the different species (1-way ANOSIM; Global $\mathrm{R}=-0.06 ; \mathrm{p}=0.83$ ).

The majority of the plastic items were microplastic $(n=45,86 \%)$. These were predominantly small microplastic $(<1 \mathrm{~mm})$, which compromised $65 \%$ of all retrieved items $(\mathrm{n}=34)$, while large microplastic $(1-5 \mathrm{~mm})$ compromised $21 \%$ of all items $(\mathrm{n}=11)$ (Fig. 2). The remaining proportion (14\%) corresponded to meso and macroplastics. We further report this data in Table 2to demonstrate the size breakdown of plastics recovered in each species.

Although all the larger plastic items were found in skipjack tunas and chub mackerels, no significant differences were detected in the average size of the plastic items between fish species (Chi square $=4.96 ; \mathrm{p}=0.29 ; \mathrm{df}=4)$ or habitat $($ Chi square $=1.95 ; \mathrm{p}=0.16 ; \mathrm{df}=1)$. When pooling all species together, we found a significant, but weak correlation between fish length and plastic item size $\left(R^{2}=0.074 ; p=0.05\right)$ (Fig. 3). Plastic fragments dominated the small microplastic $(n=$ $28,82 \%)$, while large microplastic had similar proportion of fibres and fragments $(n=6,54 \%$ and $\mathrm{n}=5,46 \%$, respectively). Meso and macroplastics were mostly threads $(\mathrm{n}=6)$ and to a lesser extent fragments $(n=1)$.

Overall, blue was the most common colour of the plastic item recovered (34.6\%) (Fig. 4A), followed equally by green and black (23.1\%). The other colours of items recovered were red and white/transparent (Fig. 4A). When looking at the colours of plastics recovered by species, blue was the dominant colour in blackbelly rosefish and blue jack mackerel, green was only found and found most frequently in chub mackerel and blackspot seabream, while black was the most common in skipjack tuna. Results from ANOSIM showed that there was not a significant preference in terms of colour between pelagic and benthic fish species (1-way ANOSIM; Global $\mathrm{R}=-0.04 ; \mathrm{p}=0.73$ ) and between individual species (1-way ANOSIM; Global $\mathrm{R}=0.03 ; \mathrm{p}=0.18$ ).

Nine different polymers were identified (Fig. 4B): polyethylene (PE), polyester (PES), polypropylene (PP), polyethylene terephthalate (PET), polyvinyl chloride (PVC), polyacrylonitrile (PAN), polystyrene (PS), polyamide resin (PA) and polynorbornene (PNR). The most common polymer was PE (42.3\% of all particles analysed), followed by PP (15.4\%), PCT and PES (11.5\% respectively). Although PE was the most abundant polymer recovered, it was 
only found in the pelagic species. PES was present in all species, except for blackspot seabream species, and PP items were present in all species, except for blue jack mackerel (Fig. 4B). PVC was only found in skipjack tuna, PA in chub mackerel and PNR in blue jack mackerel (Fig. 4B). Results from ANOSIM showed that there were significant differences in polymer type of the plastic items between pelagic and benthic fishes (1-way ANOSIM; Global $\mathrm{R}=0.23 ; \mathrm{p}=0.03$ ) and between some species (1-way ANOSIM; Global $\mathrm{R}=0.17 ; \mathrm{p}=0.03$ ). According to SIMPER analysis, the dissimilarity between the two habitats was mostly driven by PP and PE, as the plastic items recovered from the two benthic species where almost exclusively PP and in the pelagic species PE was most common (Fig. 4B). Furthermore, pelagic species contained a wider diversity of polymers compared to benthic species.

When investigating polymer type by shape, $66.7 \%$ of thread-like items were made of $\mathrm{PP}(\mathrm{n}=$ 4) and $33.3 \%$ of PE $(n=2)$. The majority of fragments were PE $(n=18,52.9 \%)$, but also PET ( $n=$ $5,14.7 \%)$ and $P P(n=4,11,8 \%)$. PES, PS and PAN were only identified in fibres. PES represented $50 \%(n=6)$ and PAN $25 \%(n=3)$ of fibres. In addition, $16.7 \%$ of fibres $(n=2)$ were identified as being PE and the remaining as PS (8.3\%).

\section{Discussion}

Our results reveal that all five species of fish studied here, occupying multiple oceanic zones of the Azores, had plastic in their stomach, indicating ingestion. All five species are principal target species of local fisheries and are of high market value (Pham et al., 2013b). Fisheries in the Azores are mostly artisanal and place a high value on fish quality and on sustainable capture methods. Therefore, these results may have knock on implications for such high-quality fish products. In addition, two of the investigated species (chub mackerel and blue jack mackerel) are key components of the Azorean marine food web, acting as prey items for large pelagic fish species such as tunas, but also for seabirds and many cetaceans (Morato et al., 2016).

The proportion of individuals containing plastic across all species was $9.49 \%$, which was lower than initially expected considering the region's proximity to the North Atlantic subtropical gyre and the elevated ingestion of small plastic fragments previously reported for loggerhead turtles inhabiting this region ( $83 \%$ of individuals containing plastic with an average of 16 items per turtle, Pham et al., 2017). To our knowledge, there are no studies reporting plastic content in fish from the North Atlantic subtropical gyre available for direct comparison with our data. However, studies investigating plastic content in fish from the South and North Pacific subtropical gyre can be used to put our results into context. In our study the percentage of individuals containing plastic was lower than those reported in fish from the South and North Pacific subtropical gyre (35\%, Boerger et al., 2010; 24.5\%, Jantz et al., 2013; 27.3\%, Markic et al., 2018), which might reflect the higher abundance of plastic debris in the Pacific compared to the Atlantic gyres (van Sebille et al., 2015). In terms of plastic load per fish however, Azorean fishes were 
contaminated with similar amounts of plastic items $(1.4 \pm 0.04$ items $)$ to other studies (e.g. 1.7 items reported by Jantz et al. (2013); 1.15 items reported by Davison and Asch (2011)). Other studies report higher contamination levels (e.g. 2.4 items reported by Markic et al. (2018); 5.85 items reported by Boerger et al. (2010)) however, such comparisons should be treated with caution given inherent differences in the type of species investigated, which possess distinct ecological characteristics (feeding ecology, habitat use, etc...), and also due to differences in the methods used to isolate and quantify microplastic. The detection of smaller plastic items remains a challenging task, and may have been under-estimated due to their size. In the future, recovery testing should be included to give a quantifiable measure of recovery accuracy both based on size, shape, and potentially colour. This was not carried out in this case due to the need for replication and opportunistic nature of the fish collection from the fishing industry.

Within the wider North Atlantic basin, the number of fish containing plastic in our study (9.49\%) is similar to that reported by Lusher et al. (2016) for mesopelagic species (11\%) but low compared to studies from the populated coastlines of Portugal (19.8\%, Neves et al., 2015; 38\% Bessa et al., 2018; 35\%, Barboza et al., 2020), Spain (17.5\%, Bellas et al,. 2016) and even the Canary Islands (78.3\%, Herrera et al., 2019). This suggests that although the Azores are found in the vicinity of large accumulation zone (at the scale of the North Atlantic), the quantities of microplastic in urban areas can reach concentrations that lead to subsequent elevated ingestion in fishes. Plastic fragments were the most abundant shape recovered in all the species investigated herein, consistent with what has been found in fishes from plastic accumulation zones in the open ocean (Boerger et al., 2010; Davison and Asch, 2011; Jantz et al., 2013; Markic et al., 2018). On the other hand, studies in populated regions closer to the coast typically find that fibres are the most abundant shape recovered from the guts of fish sampled (Neves et al., 2015; Bellas et al., 2016; Güven et al., 2017; Peters et al., 2017; Bessa et al., 2018; Herrera et al., 2019; Barboza et al. 2020).

Regional differences within similar species suggest that the chub mackerel from the Azores have a lower proportion of plastic content ( $16.7 \%$ contained plastic) than what is reported by other authors in different regions of the North Atlantic (31\%, Neves et al., 2015; 78.3\%, Herrera et al., 2019; 46\% Barboza et al. 2020) and in the Mediterranean Sea (71\%, Güven et al., 2017; 43\%, Anastasopoulou et al., 2018). Again, the lower plastic uptake for this species in the Azores may be explained by the fact that this region has lower population density than cities such as Lisbon (Neves et al., 2015), the Canary Islands (Herrera et al., 2019) and the heavily populated Mediterranean coastline (Güven et al., 2017; Anastasopoulou et al., 2018). While fragments where the most common shape recovered from Azorean chub mackerels, in the Canary Islands, fibres of an unknown polymer were dominating this species (Herrera et al., 2019). Most fibres initially identified in our results were found to be cellulose, with great uncertainty as to their origin. Cellulose items were not included in our results and that may further explain such a 
difference in the number of chub mackerel with plastic compared to other studies that reported significant amount of fibres in this species (e.g. Güven et al., 2017; Anastasopoulou et al., 2018; Herrera et al., 2019; Barboza et al., 2020).

The proportion of blue jack mackerel containing plastic in our study (7.69\%) was slightly higher than the $3 \%$ reported for 29 individuals of this species off the coast of mainland Portugal (Neves et al., 2015). Yet, our differing methodology (complete digestion of the stomach) together with a larger sample size might explain such differences in the overall load of plastic detected. Our data are also lower than others investigating Trachurus spp. that of Lusher et al. (2013) (UK), Anastasopoulou et al. (2018) (Southern Adriatic), and Güven et al. (2017) (Turkish Mediterranean) who report average microplastic abundances of $0.42,0.52$, and 1.77 plastic particles per individual respectively compared to our 0.12 items per individual.

Similarly, the higher quantities of plastic content we found in the skipjack tuna of the Azores compared to specimens sampled in the South West Pacific (0\%, Rochman et al., 2015; 0\%, Cannon et al., 2016) and South coast of India (Sathish et al., 2020), reporting plastic contamination of 2 items ( 1 fibre and 1 fragment), is probably due to sample size $(<10$ individuals in these studies ). Conversely Markic et al., (2018) (also sampling 10 individuals) reported a much higher incidence of microplastic ingestion of 2.20 items per individual yellowfin tuna (caught in Rapa Nui) compared to our 0.16 items per individual in skipjack tuna. Therefore, developing reasoning to explain regional differences in plastic content for this species is somewhat difficult.

Studies investigating seabreams (Pagellus spp.) similarly vary around our average incidence of microplastic contamination. Our data report 0.04 items per individual of blackspot seabream whereas data collected by Anastasopoulou et al. (2018) (Northern Adriatic and NE Ioanian Sea) report average abundances of 0.03 and 0.02 items per individual respectively by region. Güven $e t$ al. (2017) (Turkish Mediterranean) report abundances of 0.63 and 1.63 items per individual and Digka et al. (2018) (Northern Ionian Sea) found abundances of 0.8 items per fish; both higher than our abundances.

The only study reporting plastic contamination in blackbelly rosefish of the Atlantic did not detect any plastic items (Neves et al., 2015) but again, this assessment was based on a single individual and using only visual analysis. In the Mediterranean Sea, Anastasopoulou et al., (2013) also did not recover any plastic items from this species despite their large sample size (exceeding 300 individuals). Yet their analysis was also limited to visual detection of items larger than $1 \mathrm{~mm}$, thereby, overlooking some of the smallest particles that we were able to recover through a complete digestion of the stomachs. Restricting our results to items larger than $1 \mathrm{~mm}$, the proportion of blackbelly rosefish in the Azores with plastic would be also null (Table 2), since we only found items smaller than $1 \mathrm{~mm}$.

Collectively, these observations further point out that with the absence of standardized methodologies, comparisons between studies are challenging and often meaningless. While 
results based on small sample sizes and that does not include chemical confirmation (e.g. FTIR) cannot be corrected, it is still possible to compare between studies that where limited in the detection of smaller items given that the authors explicitly report the quantities of the plastics recovered by different size classes such as provided here.

It is important to highlight that other aspects of the methods can influence the quantities of plastic contents in wild caught fish. An important bias recognised in dietary studies of deep-sea fish is stomach eversion, caused by sudden changes in pressure as the fish is brought to the surface (Vinson and Angradi, 2011). Fish with everted stomachs usually are ignored in dietary studies since it can bias calculations of food consumption rates (e.g., Stevens and Dunn, 2011, Horn et al., 2012). Accordingly, we have followed this guideline and excluded any individuals showing signs of stomach eversion. The fact that we found $47 \%$ of our blackbelly rosefish with empty stomachs could indicate eversion however our data are in accordance with other studies investigating diet in this species (between 40 and 50\%, Nouar and Maurin, 2000; Colloca et al., 2010; Consoli et al., 2010; Neves et al., 2012) and this reflects a normal condition in this species. The elevated number of empty stomachs of the blackbelly rosefish compared to other species reflects the species' feeding strategy which is primarily a daytime predator feeding during a relative short period, after which it remains inactive and does not ingest prey until the previous prey item has been fully digested (Macpherson, 1985). No specimens of the other deep-sea species (blackspot seabream) analysed were found with empty stomachs, suggesting that our capture method was not promoting loss of stomach content.

In what comparisons we were able to make it is clear that globally our fishes are on the lower end of ingestion compared to other studies but are by no means the lowest. However, the aforementioned caveats and confounding differences that make comparisons difficult must be considered when comparing studies.

Our results reveal that the stomachs of pelagic species were found to contain plastics more frequently than deep-water species, which is in agreement with a number of other studies across the globe (Avio et al., 2020; Romeo et al., 2015; Battaglia et al., 2016; Nadal et al., 2016; Anastasopoulou et al., 2018). However, some studies do report equitable amounts of plastics in fishes from the two ocean compartments (Lusher et al., 2013; de Vries et al., 2020), whilst others report the opposite, with greater proportions of benthic species ingesting plastic compared to pelagic species (Markic et al., 2018, Kühn et al., 2019). Such disagreement most likely reflects the patchy distribution of plastics in the oceans and the biological and ecological dynamics that play out when capturing fishes at one time point. It is well documented that in our study region, floating debris are particularly abundant due to the presence of a major large-scale convergence zone (Cózar et al., 2014; Eriksen et al., 2014; Van Sebille et al., 2020). However, the spatiotemporal distribution of microplastic can vary greatly as demonstrated by Law et al., (2014) who documented 3 orders of magnitude difference in plastic abundances between sites in close 
proximity sampled within a 24 -hour period. A further complication is that oceanographic and biological processes might inhibit or increase vertical transport of plastic down to the seabed by changing their density (Cole et al., 2016; Galloway et al., 2017; Porter et al., 2018; Van Sebille et al., 2020). These processes can even alter their bioavailability by changing the palatability of these plastics to organisms (Rummel et al., 2017; Hodgson et al., 2018; Porter et al., 2019). These factors can further alter the distribution, uptake and fate of plastics in the ocean and may go some way to explain the heterogeneity of data seen in review of the available literature.

Another difference between fishes from both compartments, was that the deep-water species had only small microplastic $(<1 \mathrm{~mm})$, while the stomach content of the pelagic species included a wider size range (and polymer), having more often items larger than $5 \mathrm{~mm}$. This in agreement with the results of Avio et al. (2020) who found that benthic species in the Adriatic Sea have a higher proportion of small microplastic compared to pelagic species. The vertical transport of plastics in the ocean is associated with biological interactions (e.g. biofouling, marine snow, faecal pellets, plastic pump), implying that small microplastic might be more abundant in the deep sea than larger plastics (van Sebille et al., 2020).

We found that blue items were the most common colour in plastic items in the stomach content, which has now been reported in a number of other studies (Boerger et al., 2010; Güven et al., 2017; Ory et al., 2017; Peters et al., 2017; Herrera et al., 2019; Barboza et al., 2020). It has been suggested that an active selection for blue coloured plastic items might occur, due to misidentification of plastics for natural prey items in pelagic species which are mostly visual predators feeding on small blue coloured zooplankton (Neves et al., 2015; Ory et al., 2017; Herrera et al. 2019). In the Azores, white fragments are by far the most abundant colour of microplastic stranded on the coastline but also floating at the surface (Pham et al., 2020), providing additional evidence that fish actively ingest significantly higher quantities of blue particles because this is the colour of their typical prey items rather than because they are more abundant in the environment. The predominance of small blue plastic items also found in the larger ambush predator of the deep-sea in the Azores, such as the blackbelly rosefish might indicate a potential trophic transfer of small blue plastic items mistakenly ingested by their prey.

The other large predatory species included in this study, the skipjack tuna, is known to feed on large prey items, including fish and cephalopods, resulting in a more selective predatory activity. The predatory feeding mode of tuna together with the small size of microplastic found in their guts would suggest that it is less likely that the skipjack tuna misidentifies plastic items as prey, but rather ingests them through prey items or incidentally during normal feeding behaviour in the case of large threads (up to $11 \mathrm{~cm}$ ) found in this species.

The variation in polymers recovered from both oceanic compartments can be partially explained by their inherent properties. Polyethylene (PE), polypropylene (PP), and polystyrene (PS) all float in seawater due to their density when virgin particles. PE and PP made up $\sim 58 \%$ of 
the total polymers found in our study which is unsurprising as PE a PP account for $49 \%$ of resins produced by demand in Europe (Plastics Europe, 2019) and due to their aforementioned buoyancy as virgin polymers. This explains the absence of PE and PS in our benthic species however our benthic species were found with PP in their stomachs. This is most likely due to biofouling and subsequent vertical transport. Biofouling can start within hours of plastics entering the marine environment (Ye and Andrady, 1991) and this will eventually act to alter the particles density and cause it to sink (Gregory, 2009; Kooi et al., 2017). This coupled with the aforementioned vertical transport mechanisms of microplastic enables buoyant polymers to be found in deep water or benthic species. Polyesters (PES), and Polyvinylchloride (PVC) are notably denser than seawater and yet are found in our pelagic species. As these species have a varied feeding depth distribution there are a number of factors that could lead to this occurrence. Firstly, the particles may well have been sinking when consumed; the original input location is not known. Furthermore, these particles may have recently fragmented from a larger buoyant macroplastic piece floating due to its construction (shape or air pockets) and as it degrades these ingested particles may have flaked off the original product. Finally, these particles, especially for PES may have been transported to these locations by aeolian processes driving fragments or fibres the continental land masses (Enders et al., 2015)

Stomach content alone does not reflect the true extent of plastic content of a species, especially given the dynamics of egestion and trophic transfer potential to confound these data. Both small and large (up to $5 \mathrm{~mm}$ ) plastic items have been found in the muscle and gills of different fish species (Abbasi et al., 2018, Akhbarizadeh et al., 2018; Barboza et al., 2020) but the exact mechanism of internalisation is still not well understood. Therefore, it is highly probable that the total plastic load of the species investigated herein could be underestimated, but this certainly does not affect the relevance of our findings based on stomach contents.

\section{Conclusions}

Overall, our findings confirm the presence of plastic particles in all five commercially important fish species investigated from the Azores archipelago, with most items being smaller than $1 \mathrm{~mm}$ in size. The general proportion of individuals containing plastics for these species however was low compared to other areas in the North Atlantic demonstrating the challenges of inter-study comparison. Our results highlight differences in the frequency and abundance of plastic items present in the stomach contents of pelagic and benthic species with open-ocean pelagic species having ingested significantly more plastics of distinct polymer types compared to benthic species. In pelagic fish polyethylene was most abundant polymer while plastics in deepsea fish were almost exclusively polypropylene. We highlight the importance of performing $\mu$ FTIR or other polymer identification methods for validating results, particularly when looking at small microplastic items. In this study, a total of 190 items initially identified as likely plastic 
items ( $80 \%$ being smaller $1 \mathrm{~mm}$ ) using visual methods only were rejected from our analysis due to non-plastic matches with spectral libraries or low-quality spectral matches, and this misidentification could lead to an overestimation in the frequency of plastic content in studies that do not employ these techniques. Furthermore, we emphasize the importance of having a substantial sample size (at least minimum of 40-50 individuals per species) to ensure that the issues surrounding time of feeding, ingestion, and egestion amongst other biological dynamics do not confound results.

\section{Acknowledgements}

This research has received funding from the program POCORES2020 under the project LIXAZ (ACORES-01-0145-FEDER-000053). The authors wish to thank the collaboration of the national program for fisheries data collection and COFACO for the help in collecting the fish. CL and AP were supported by NERC HT grant MINIMISE NE/S003975/1. We would like to especially thank Dalia Reis, Angela Canha, João Frias, Hugo Diogo, Filipe Porteiro for their collaboration. Access to the PerkinElmer Frontier FT-IR spectrometer and Spotlight 400 imaging FT-IR microscopy system was made possible under a Research Partnership Agreement between the Greenpeace Research Laboratories and PerkinElmer. We wish to thank David Santillo at Greenpeace for his continued support, wisdom, and for access to the FTIR system.

4

\section{References}

Abbasi, S., Soltani, N., Keshavarzi, B., Moore, F., Turner, A., Hassanaghaei, M. (2018). Microplastics in different tissues of fish and prawn from the Musa Estuary, Persian Gulf. Chemosphere, 205, 80-87.

Akhbarizadeh, R., Moore, F., Keshavarzi, B. (2018). Investigating a probable relationship between microplastics and potentially toxic elements in fish muscles from northeast of Persian Gulf. Environmental pollution, 232, 154-163.

Anastasopoulou, A., Mytilineou, C., Smith, C. J., Papadopoulou, K. N. (2013). Plastic debris ingested by deep-water fish of the Ionian Sea (Eastern Mediterranean). Deep Sea Research Part I: Oceanographic Research Papers, 74, 11-13.

Anastasopoulou, A., Viršek, M. K., Varezić, D. B., Digka, N., Fortibuoni, T., Koren, Š., Mandíc, M., Mytilineou, C., Pešic, A., Ronchi, F., Šilijić, J., Torre, M., Tsangaris, C., Tutman, P. (2018). Assessment on marine litter ingested by fish in the Adriatic and NE Ionian Sea macro-region (Mediterranean). Marine pollution bulletin, 133, 841-851. 
Avio, C. G., Pittura, L., d’Errico, G., Abel, S., Amorello, S., Marino, G., Gorbi, S., Regoli, F. (2020). Distribution and characterization of microplastic particles and textile microfibers in Adriatic food webs: General insights for biomonitoring strategies. Environmental Pollution, 258, 113766.

Barboza, L. G. A., Lopes, C., Oliveira, P., Bessa, F., Otero, V., Henriques, B., Raimundo, J., Caetano, M., Vale, C., Guilhermino, L. (2020). Microplastics in wild fish from North East Atlantic Ocean and its potential for causing neurotoxic effects, lipid oxidative damage, and human health risks associated with ingestion exposure. Science of the Total Environment, 717, 134625.

Barnes, D. K., Galgani, F., Thompson, R. C., Barlaz, M. (2009). Accumulation and fragmentation of plastic debris in global environments. Philosophical Transactions of the Royal Society B: Biological Sciences, 364(1526), 1985-1998.

Battaglia, P., Pedà, C., Musolino, S., Esposito, V., Andaloro, F., Romeo, T. (2016). Diet and first documented data on plastic ingestion of Trachinotus ovatus L. 1758 (Pisces: Carangidae) from the Strait of Messina (central Mediterranean Sea). Italian Journal of Zoology, 83(1), 121-129.

Bellas, J., Martínez-Armental, J., Martínez-Cámara, A., Besada, V., Martínez-Gómez, C. (2016). Ingestion of microplastics by demersal fish from the Spanish Atlantic and Mediterranean coasts. Marine pollution bulletin, 109(1), 55-60.

Bessa, F., Barría, P., Neto, J. M., Frias, J. P., Otero, V., Sobral, P., Marques, J. C. (2018). Occurrence of microplastics in commercial fish from a natural estuarine environment. Marine pollution bulletin, 128, 575-584.

Boerger, C. M., Lattin, G. L., Moore, S. L., \& Moore, C. J. (2010). Plastic ingestion by planktivorous fishes in the North Pacific Central Gyre. Marine pollution bulletin, 60(12), 2275-2278.

Bolten, A. B. (2003). Active swimmers-passive drifters: the oceanic juvenile stage of loggerheads in the Atlantic system. Loggerhead sea turtles, 63-78.

Braga-Henriques, A., Porteiro, F.M., Ribeiro, P.A., de Matos,V., Sampaio, I., Ocaña, O., Santos, R.S. (2013). Diversity, distribution and spatial structure of the cold-water coral fauna of the Azores (NE Atlantic). Biogeosciences. 10, 4009-4036.

Bray, L., Digka, N., Tsangaris, C., Camedda, A., Gambaiani, D., de Lucia, G. A., Matiddi, M., Miaud, C., Palazzo, L., Pérez-del-Olmo, A., Raga, J. A., Silvestri, C., Kaberi, H. (2019). 
Determining suitable fish to monitor plastic ingestion trends in the Mediterranean Sea. Environmental pollution, 247, 1071-1077.

Browne, M. A., Crump, P., Niven, S. J., Teuten, E., Tonkin, A., Galloway, T., Thompson, R. (2011). Accumulation of microplastic on shorelines worldwide: sources and sinks. Environmental science \& technology, 45(21), 9175-9179.

Cannon, S. M., Lavers, J. L., Figueiredo, B. (2016). Plastic ingestion by fish in the Southern Hemisphere: A baseline study and review of methods. Marine pollution bulletin, 107(1), 286-291.

Castro, J. J. (1993). Feeding ecology of chub mackerel Scomber japonicus in the Canary Islands area. South African Journal of Marine Science, 13(1), 323-328.

Chambault, P., Vandeperre, F., Machete, M., Lagoa, J. C., Pham, C. K. (2018). Distribution and composition of floating macro litter off the Azores archipelago and Madeira (NE Atlantic) using opportunistic surveys. Marine environmental research, 141, 225-232.

Chiba, S., Saito, H., Fletcher, R., Yogi, T., Kayo, M., Miyagi, S., Ogido, M., Fujikura, K. (2018). Human footprint in the abyss: 30 year records of deep-sea plastic debris. Marine Policy, 96, 204-212.

Cole, M., Lindeque, P. K., Fileman, E., Clark, J., Lewis, C., Halsband, C., Galloway, T. S. (2016). Microplastics alter the properties and sinking rates of zooplankton faecal pellets. Environmental science \& technology, 50(6), 3239-3246.

Collette, B. B., Nauen, C. E. (1983). FAO species catalogue. Volume 2. Scombrids of the world. An annotated and illustrated catalogue of tunas, mackerels, bonitos and related species known to date (No. 125).

Colloca, F., Carpentieri, P., Balestri, E., Ardizzone, G. (2010). Food resource partitioning in a Mediterranean demersal fish assemblage: the effect of body size and niche width. Marine Biology, 157(3), 565-574.

Consoli, P., Battaglia, P., Castriota, L., Esposito, V., Romeo, T., Andaloro, F. (2010). Age, growth and feeding habits of the bluemouth rockfish, Helicolenus dactylopterus dactylopterus (Delaroche 1809) in the central Mediterranean (southern Tyrrhenian Sea). Journal of Applied Ichthyology, 26(4), 583-591.

Cózar, A., Echevarría, F., González-Gordillo, J. I., Irigoien, X., Úbeda, B., Hernández-León, S., Palma, Á. T., Navarro, S., García-de-Lomas, J., Ruiz, A., Fernández-de-Puelles, M. L., Duarte, C. M. (2014). Plastic debris in the open ocean. Proceedings of the National Academy of Sciences, 111(28), 10239-10244. 
Das, D., Afonso, P. (2017). Review of the diversity, ecology, and conservation of elasmobranchs in the Azores region, mid-north Atlantic. Frontiers in Marine Science, 4, 354.

Davison, P., Asch, R. G. (2011). Plastic ingestion by mesopelagic fishes in the North Pacific Subtropical Gyre. Marine Ecology Progress Series, 432, 173-180.

Davidson, T. M. (2012). Boring crustaceans damage polystyrene floats under docks polluting marine waters with microplastic. Marine Pollution Bulletin, 64(9), 1821-1828.

Dehaut, A., Cassone, A.-L., Frere, L., Hermabessiere, L., Himber, C., Rinnert, E., Rivière, G., Lambert, C., Soudant, P., Huvet, A., Duflos, G., Paul-Pont I. (2016). Microplastics in seafood: benchmark protocol for their extraction and characterization. Environmental Pollution, 215, 223-233.

de Vries, A. N., Govoni, D., Árnason, S. H., Carlsson, P. (2020). Microplastic ingestion by fish: Body size, condition factor and gut fullness are not related to the amount of plastics consumed. Marine Pollution Bulletin, 151, 110827.

Digka, N., Tsangaris, C., Torre, M., Anastasopoulou, A., Zeri, C. (2018). Microplastics in mussels and fish from the Northern Ionian Sea. Marine pollution bulletin, 135, 30-40.

Do Sul, J. A. I., Costa, M. F., Fillmann, G. (2014). Microplastics in the pelagic environment around oceanic islands of the Western Tropical Atlantic Ocean. Water, Air, \& Soil Pollution, 225(7), 2004.

Enders, K., Lenz, R., Stedmon, C. A., Nielsen, T. G. (2015). Abundance, size and polymer composition of marine microplastics $\geq 10 \mu \mathrm{m}$ in the Atlantic Ocean and their modelled vertical distribution. Marine pollution bulletin, 100(1), 70-81.

Eriksen, M., Lebreton, L. C., Carson, H. S., Thiel, M., Moore, C. J., Borerro, J. C., Galgani, F., Ryan, P.G., Reisser, J. (2014). Plastic pollution in the world's oceans: more than 5 trillion plastic pieces weighing over 250,000 tons afloat at sea. PloS one, 9(12), e111913.

Everaert, G., Van Cauwenberghe, L., De Rijcke, M., Koelmans, A. A., Mees, J., Vandegehuchte, M., Janssen, C. R. (2018). Risk assessment of microplastics in the ocean: Modelling approach and first conclusions. Environmental Pollution, 242, 1930-1938.

Foekema, E. M., De Gruijter, C., Mergia, M. T., van Franeker, J. A., Murk, A. J., Koelmans, A. A. (2013). Plastic in north sea fish. Environmental science \& technology, 47(15), 88188824.

Gall, S. C., Thompson, R. C. (2015). The impact of debris on marine life. Marine Pollution Bulletin, 92(1-2), 170-179. 
Galloway, T. S., Cole, M., Lewis, C. (2017). Interactions of microplastic debris throughout the marine ecosystem. Nature ecology \& evolution, 1(5), 0116.

Gregory, M. R. (2009). Environmental implications of plastic debris in marine settingsentanglement, ingestion, smothering, hangers-on, hitch-hiking and alien invasions. Philosophical Transactions of the Royal Society B: Biological Sciences, 364(1526), 2013-2025.

Güven, O., Gökdağ, K., Jovanović, B., Kıdeyş, A. E. (2017). Microplastic litter composition of the Turkish territorial waters of the Mediterranean Sea, and its occurrence in the gastrointestinal tract of fish. Environmental Pollution, 223, 286-294.

Herrera, A., Ŝtindlová, A., Martínez, I., Rapp, J., Romero-Kutzner, V., Samper, M. D., Montoto, T., Aguiar-González, B., Gómez, M. (2019). Microplastic ingestion by Atlantic chub mackerel (Scomber colias) in the Canary Islands coast. Marine pollution bulletin, 139, 127135.

Hodgson, D. J., Bréchon, A. L., Thompson, R. C. (2018). Ingestion and fragmentation of plastic carrier bags by the amphipod Orchestia gammarellus: effects of plastic type and fouling load. Marine pollution bulletin, 127, 154-159.

Horn, P. L., Forman, J. S., Dunn, M. R. (2012). Dietary partitioning by two sympatric fish species, red cod (Pseudophycis bachus) and sea perch (Helicolenus percoides), on Chatham Rise, New Zealand. Marine Biology Research, 8(7), 624-634.

Jantz, L. A., Morishige, C. L., Bruland, G. L., Lepczyk, C. A. (2013). Ingestion of plastic marine debris by longnose lancetfish (Alepisaurus ferox) in the North Pacific Ocean. Marine pollution bulletin, 69(1-2), 97-104.

Karami, A., Golieskardi, A., Choo, C. K., Romano, N., Ho, Y. B., Salamatinia, B. (2017). A highperformance protocol for extraction of microplastics in fish. Science of the Total Environment, 578, 485-494.

Koelmans, A. A., Kooi, M., Law, K. L., Van Sebille, E. (2017). All is not lost: deriving a topdown mass budget of plastic at sea. Environmental Research Letters, 12(11), 114028.

Kooi, M., Nes, E. H. V., Scheffer, M., Koelmans, A. A. (2017). Ups and downs in the ocean: effects of biofouling on vertical transport of microplastics. Environmental science \& technology, 51(14), 7963-7971.

Kühn, S., van Franeker, J. A., O'donoghue, A. M., Swiers, A., Starkenburg, M., van Werven, B., Foekema, E., Hermsen, E., Egelkraut-Holtus, M., Lindeboom, H. (2019). Details of plastic ingestion and fibre contamination in North Sea fishes. Environmental Pollution, 113569. 
Law, K. L., Morét-Ferguson, S., Maximenko, N. A., Proskurowski, G., Peacock, E. E., Hafner, J., Reddy, C. M. (2010). Plastic accumulation in the North Atlantic subtropical gyre. Science, 329(5996), 1185-1188.

Law, K. L., Morét-Ferguson, S. E., Goodwin, D. S., Zettler, E. R., DeForce, E., Kukulka, T., Proskurowski, G. (2014). Distribution of surface plastic debris in the eastern Pacific Ocean from an 11-year data set. Environmental science \& technology, 48(9), 4732-4738.

Lusher, A. L., McHugh, M., Thompson, R. C. (2013). Occurrence of microplastics in the gastrointestinal tract of pelagic and demersal fish from the English Channel. Marine pollution bulletin, 67(1-2), 94-99.

Lusher, A. L., O'Donnel, C., Officer, R., and O' Connor, I. (2016). Microplastic interactions with North Atlantic mesopelagic fish. ICES Journal of Marine Science, 73, 1214-1225.

Lusher, A. L., Welden, N. A., Sobral, P., Cole, M. (2017). Sampling, isolating and identifying microplastics ingested by fish and invertebrates. Analytical Methods, 9(9), 1346-1360.

Macpherson E. (1985). Daily ration and feeding periodicity of some fishes off the coast of Namibia. Marine Ecology Progress Series 26:253- 260

Markic, A., Niemand, C., Bridson, J. H., Mazouni-Gaertner, N., Gaertner, J. C., Eriksen, M., Bowen, M. (2018). Double trouble in the South Pacific subtropical gyre: Increased plastic ingestion by fish in the oceanic accumulation zone. Marine pollution bulletin, 136, 547564.

Markic, A., Gaertner, J. C., Gaertner-Mazouni, N., Koelmans, A. A. (2019). Plastic ingestion by marine fish in the wild. Critical Reviews in Environmental Science and Technology, 1-41.

Massutí, E., Moranta, J., De Sola, L. G., Morales-Nin, B., Prats, L. (2001). Distribution and population structure of the rockfish Helicolenus dactylopterus (Pisces: Scorpaenidae) in the western Mediterranean. Journal of the Marine Biological Association of the United Kingdom, 81(1), 129-141.

Menezes, G. M., Sigler, M. F., Silva, H. M., Pinho, M. R. (2006). Structure and zonation of demersal fish assemblages off the Azores Archipelago (mid-Atlantic). Marine Ecology Progress Series, 324, 241-260.

Miller, D. J., Lea, R. N. (1972). Guide to the coastal marine fishes of California (No. 154-158). UCANR Publications.

Monteiro, L. R., Ramos, J. A., Furness, R. W. (1996). Past and present status and conservation of the seabirds breeding in the Azores archipelago. Biological conservation, 78(3), 319-328. 
Morato, T., E. Solà, M.P. Grós and G. Menezes. (2001). Feeding habits of two congener species of seabreams, Pagellus bogaraveo and Pagellus acarne, off Azores (northeastern Atlantic) during spring of 1996 and 1997. Bulletin of Marine Science 69 (3): 1073-1087.

Morato, T., Lemey, E., Menezes, G., Pham, C. K., Brito, J., Soszynski, A., Pitcher, T. J., Heymans, J. J. (2016). Food-web and ecosystem structure of the open-ocean and deep-sea environments of the Azores, NE Atlantic. Frontiers in Marine Science, 3, 245.

Munari, C., Infantini, V., Scoponi, M., Rastelli, E., Corinaldesi, C., Mistri, M. (2017). Microplastics in the sediments of Terra Nova Bay (Ross Sea, Antarctica). Marine pollution bulletin, 122(1-2), 161-165.

Murphy, F., Russell, M., Ewins, C., Quinn, B. (2017). The uptake of macroplastic \& microplastic by demersal \& pelagic fish in the Northeast Atlantic around Scotland. Marine pollution bulletin, 122(1-2), 353-359.

Nadal, M. A., Alomar, C., Deudero, S. (2016). High levels of microplastic ingestion by the semipelagic fish bogue Boops boops (L.) around the Balearic Islands. Environmental Pollution, 214, 517-523.

Naidoo, T., Smit, A. J., Glassom, D. (2016). Plastic ingestion by estuarine mullet Mugil cephalus (Mugilidae) in an urban harbour, KwaZulu-Natal, South Africa. African Journal of Marine Science, 38(1), 145-149.

Neves, A., Sequeira, V., Paiva, R. B., Vieira, A. R., Gordo, L. S. (2012). Feeding habits of the bluemouth, Helicolenus dactylopterus dactylopterus (Delaroche, 1809) (Pisces: Sebastidae) in the Portuguese coast. Helgoland Marine Research, 66(2), 189.

Neves, D., Sobral, P., Ferreira, J. L., Pereira, T. (2015). Ingestion of microplastics by commercial fish off the Portuguese coast. Marine pollution bulletin, 101(1), 119-126.

Nouar, A., Maurin, C. (2000). Régime alimentaire de Helicolenus dactylopterus dactylopterus (Pisces: Scorpaenidae) des fonds chalutables des côtes algériennes. Cahiers de biologie marine, 41, 313-320.

Ory, N.C., Sobral, P., Ferreira, J.L., Thiel, M., (2017). Amberstripe scad Decapterus muroadsi (Carangidae) fish ingest blue microplastics resembling their copepod prey along the coast of Rapa Nui (Easter Island) in the South Pacific subtropical gyre. Science of the Total Environment. 586, 430-437.

Peters, C. A., Thomas, P. A., Rieper, K. B., Bratton, S. P. (2017). Foraging preferences influence microplastic ingestion by six marine fish species from the Texas Gulf Coast. Marine pollution bulletin, 124(1), 82-88. 
Pham, C. K., Gomes-Pereira, J. N., Isidro, E. J., Santos, R. S., Morato, T. (2013a). Abundance of litter on condor seamount (Azores, Portugal, Northeast Atlantic). Deep Sea Research Part II: Topical Studies in Oceanography, 98, 204-208.

Pham, C. K., Canha, A., Diogo, H., Pereira, J.G., Prieto, R., Morato, T. (2013b). Total marine fishery catch for the Azores (1950-2010). ICES Journal of Marine Science.70, 564-577.

Pham, C. K., Ramirez-Llodra, E., Alt, C. H., Amaro, T., Bergmann, M., Canals, M., Company, J. B., Davies, J., Duineveld, G., Galgani, F., Howel, K. L., Huvenne, V. A., Isidro, E., Jones, D. O. B., Lastras, G., Morato, T., Gomes-Pereira, J. N., Puser, A., Stewart, H., Tojeira, I., Tubau, X., Van Rooji, D., Tyler, P. A. (2014). Marine litter distribution and density in European seas, from the shelves to deep basins. PloS one, 9(4).

Pham, C. K., Vandeperre, F., Menezes, G., Porteiro, F., Isidro, E., Morato, T. (2015). The importance of deep-sea vulnerable marine ecosystems for demersal fish in the Azores. Deep Sea Research Part I: Oceanographic Research Papers, 96, 80-88.

Pham, C. K., Rodríguez, Y., Dauphin, A., Carriço, R., Frias, J. P., Vandeperre, F., Otero, V., Santos, M. R., Martins, H.R., Bolten, A. B., Bjorndal, K. A. (2017). Plastic ingestion in oceanic-stage loggerhead sea turtles (Caretta caretta) off the North Atlantic subtropical gyre. Marine pollution bulletin, 121(1-2), 222-229.

Pham, C. K., Pereira, J. M., Frias, J. P., Ríos, N., Carriço, R., Juliano, M., Rodríguez, Y. (2020). The Azores archipelago as a transitory repository for small plastic fragments floating in the North-East Atlantic. Environmental Pollution, 114494.

PLASTICS EUROPE. (2019). Plastics - the Facts 2019: An analysis of European plastics production, demand and waste data. Available: https://www.plasticseurope.org/ download file/force/3183/181 [Accessed 20/05/2020].

Porter, A., Lyons, B. P., Galloway, T. S., Lewis, C. (2018). Role of marine snows in microplastic fate and bioavailability. Environmental science \& technology, 52(12), 7111-7119.

Porter, A., Smith, K. E., Lewis, C. (2019). The sea urchin Paracentrotus lividus as a bioeroder of plastic. Science of the Total Environment, 693, 133621.

Provencher, J. F., Bond, A. L., Avery-Gomm, S., Borrelle, S. B., Rebolledo, E. L. B., Hammer, S., Kühn, S., Lavers, J. L., Mallory, M. L., Trevail, A., and Van Franeker, J. A. (2017). Quantifying ingested debris in marine megafauna: a review and recommendations for standardization. Analytical Methods, 9(9), 1454-1469.

R Core Team (2018). R: A language and environment for statistical computing. R Foundation for Statistical Computing, Vienna, Austria. URL https://www.R-project.org/. 
Ríos, N., Frias, J. P., Rodríguez, Y., Carriço, R., Garcia, S. M., Juliano, M., Pham, C. K. (2018). Spatio-temporal variability of beached macro-litter on remote islands of the North Atlantic. Marine pollution bulletin, 133, 304-311.

Rochman, C. M., Tahir, A., Williams, S. L., Baxa, D. V., Lam, R., Miller, J. T., The, F-C., Werorilangi, S., Teh, S. J. (2015). Anthropogenic debris in seafood: Plastic debris and fibers from textiles in fish and bivalves sold for human consumption. Scientific reports, 5 , 14340.

Rodríguez, Y., Pham, C. K. (2017). Marine litter on the seafloor of the Faial-Pico Passage, Azores Archipelago. Marine pollution bulletin, 116(1-2), 448-453.

Romeo, T., Pietro, B., Pedà, C., Consoli, P., Andaloro, F., Fossi, M. C. (2015). First evidence of presence of plastic debris in stomach of large pelagic fish in the Mediterranean Sea. Marine pollution bulletin, 95(1), 358-361.

Rummel, C. D., Löder, M. G., Fricke, N. F., Lang, T., Griebeler, E. M., Janke, M., Gerdts, G. (2016). Plastic ingestion by pelagic and demersal fish from the North Sea and Baltic Sea. Marine pollution bulletin, 102(1), 134-141.

Rummel, C. D., Jahnke, A., Gorokhova, E., Kühnel, D., Schmitt-Jansen, M. (2017). Impacts of biofilm formation on the fate and potential effects of microplastic in the aquatic environment. Environmental Science \& Technology Letters, 4(7), 258-267.

Sathish, N., Jeyasanta, I., Patterson, J. (2020). Occurrence of microplastics in epipelagic and mesopelagic fishes from Tuticorin, Southeast coast of India. Science of The Total Environment, 137614.

Scott, N., Porter, A., Santillo, D., Simpson, H., Lloyd-Williams, S., Lewis, C. (2019). Particle characteristics of microplastics contaminating the mussel Mytilus edulis and their surrounding environments. Marine Pollution Bulletin, 146, 125-133.

Silva, M. A., Prieto, R., Cascão, I., Seabra, M. I., Machete, M., Baumgartner, M. F., Santos, R. S. (2014). Spatial and temporal distribution of cetaceans in the mid-Atlantic waters around the Azores. Marine Biology Research, 10(2), 123-137.

Sobral, A. F., Afonso, P. (2014). Occurrence of mobulids in the Azores, central North Atlantic. Journal of the Marine Biological Association of the United Kingdom, 94(8), 1671-1675.

Stevens, D. W., Dunn, M. R. (2011). Different food preferences in four sympatric deep-sea Macrourid fishes. Marine biology, 158(1), 59-72. 
Sun, X., Li, Q., Zhu, M., Liang, J., Zheng, S., Zhao, Y. (2017). Ingestion of microplastics by natural zooplankton groups in the northern South China Sea.Marine pollution bulletin, 115(1-2), 217-224.

Tanaka, K., Takada, H. (2016). Microplastic fragments and microbeads in digestive tracts of planktivorous fish from urban coastal waters. Scientific reports, 6, 34351.

Ter Halle, A., Jeanneau, L., Martignac, M., Jardé, E., Pedrono, B., Brach, L., Gigault, J. (2017). Nanoplastic in the North Atlantic subtropical gyre. Environmental science \& technology, 51(23), 13689-13697.

van Sebille, E., Wilcox, C., Lebreton, L., Maximenko, N., Hardesty, B.D., VanFraneker, J.A., Eriksen, M., Siegel, D., Galgani, F., Law, K.L. (2015). A global inventory of small floating plastic debris. Environmental Research Letters. 10, 124006.

van Sebille, E., Aliani, S., Law, K. L., Maximenko, N., Alsina, J., Bagaev, A., Bergmann, M., Chapron, B., Chubarenko, I., Cózar, A., Delandmeter, P., Egger, M., Fox-Kemper, B., Garaba, S. P., Goddijn-Murphy, L., Hardesty, D., Hoffman, M. J., Isobe, A., Jongedijk, C., Kaandorp, M., Khatmullina, L., Koelmans, A. A., Kukulka, T., Laufkötter, C., Lebretinm L., Lobelle, D., Maes, C., Martinez-Vicente, V., Maqueda, M. A. M., Poulain-Zarcos, M., Rodriguez, E., Ryan, P. G., Shanks, A., Shim, W. J., Suaria, G., Thiel, M., van der Bremer, T., Wichmann, D. (2020). The physical oceanography of the transport of floating marine debris. Environmental Research Letters. in press https://doi.org/10.1088/1748$9326 / \mathrm{ab} 6 \mathrm{~d} 7 \mathrm{~d}$

Vandeperre, F., Aires-da-Silva, A., Lennert-Cody, C., Serrão Santos, R., Afonso, P. (2016). Essential pelagic habitat of juvenile blue shark (Prionace glauca) inferred from telemetry data. Limnology and Oceanography, 61(5), 1605-1625.

Vinson, M. R., Angradi, T. R. (2011). Stomach emptiness in fishes: sources of variation and study design implications. Reviews in Fisheries Science, 19(2), 63-73.

Woodall, L. C., Sanchez-Vidal, A., Canals, M., Paterson, G. L., Coppock, R., Sleight, V., Calafat, A., Rogers, A. D., Narayanaswamy, B. E., Thompson, R. C. (2014). The deep sea is a major sink for microplastic debris. Royal Society open science, 1(4), 140317.

Ye, S., Andrady, A. L. (1991). Fouling of floating plastic debris under Biscayne Bay exposure conditions. Marine pollution bulletin, 22(12), 608-613.

Zarfl, C., Matthies, M. (2010). Are marine plastic particles transport vectors for organic pollutants to the Arctic? Marine Pollution Bulletin, 60(10), 1810-1814. 
841 Table 1. Descriptive details of the individual fish collected and analysed for plastics for five 842 species from the Azores during the 2015 - 2017 sampling campaign.

843

\begin{tabular}{|c|c|c|c|c|c|c|c|}
\hline & Species & $\begin{array}{l}\text { Size } \\
\text { Class }\end{array}$ & $\begin{array}{l}\text { Number } \\
\text { of samples }\end{array}$ & $\begin{array}{c}\text { Mean } \\
\text { length }(\mathrm{cm}) \\
\pm \mathrm{SD} \\
\end{array}$ & $\begin{array}{c}\text { Length } \\
\text { range } \\
(\mathrm{cm})\end{array}$ & $\begin{array}{l}\text { Mean stomach } \\
\text { weight }(g) \pm S D\end{array}$ & $\begin{array}{c}\text { Mean } \\
\text { fullness } \\
\text { degree }\end{array}$ \\
\hline \multirow{5}{*}{ 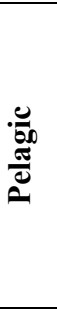 } & \multirow{2}{*}{$\begin{array}{l}\text { Chub mackerel } \\
(S . \text { colias })\end{array}$} & $\mathrm{L}$ & 50 & $43.3 \pm 2.0$ & $39.0-48.0$ & $15.0 \pm 8.7$ & $2.3 \pm 1.9$ \\
\hline & & $\mathrm{S}$ & 64 & $17.6 \pm 1.3$ & $15.5-20.5$ & $2.3 \pm 1.3$ & $3.1 \pm 1.5$ \\
\hline & Blue jack & $\mathrm{L}$ & 52 & $42.7 \pm 1.7$ & $40.0-46.5$ & $14.8 \pm 5.0$ & $1.9 \pm 1.4$ \\
\hline & $\begin{array}{c}\text { mackerel } \\
\text { (T. picturatus) }\end{array}$ & S & 65 & $15.6 \pm 0.6$ & $14.5-16.7$ & $1.5 \pm 0.7$ & $2.3 \pm 1.6$ \\
\hline & $\begin{array}{l}\text { Skipjack tuna } \\
\text { (K. pelamis) }\end{array}$ & - & 50 & $51.5 \pm 2.4$ & $45.5-57.5$ & $85.2 \pm 36.5$ & $3.8 \pm 1.4$ \\
\hline \multirow{2}{*}{ 弟 } & $\begin{array}{c}\text { Blackspot } \\
\text { seabream } \\
(P . \text { bogaraveo })\end{array}$ & - & 55 & $42.3 \pm 2.5$ & $38.0-46.5$ & $9.0 \pm 4.5$ & $2.7 \pm 0.9$ \\
\hline & $\begin{array}{c}\text { Blackbelly } \\
\text { rosefish } \\
(H . \\
\text { dactylopterus }) \\
\end{array}$ & - & 54 & $34.0 \pm 1.2$ & $32.0-36.0$ & $11.7 \pm 3.0$ & $0.7 \pm 0.8$ \\
\hline
\end{tabular}

$84 \overline{4}$

845

846

847

848

849

850

851

852

853

854

855

856

857

858

859

860

861

862

863 
Table 2. Proportion of fish with plastic in the stomach, average plastic abundance and load ( \pm $\mathrm{SE}$ ) in the stomach of five different fish species and divided for plastic of different size classes.

\begin{tabular}{|c|c|c|c|c|c|c|}
\hline \multirow[b]{2}{*}{$\begin{array}{c}\text { Plastic } \\
\text { size class }\end{array}$} & \multirow[b]{2}{*}{ Metric } & \multicolumn{3}{|c|}{ Pelagic fish } & \multicolumn{2}{|c|}{ Benthic fish } \\
\hline & & $\begin{array}{c}\text { Chub } \\
\text { mackerel } \\
(n=112)\end{array}$ & $\begin{array}{c}\text { Blue jack } \\
\text { mackerel } \\
(n=117)\end{array}$ & $\begin{array}{c}\text { Skipjack } \\
\text { tuna } \\
(n=50)\end{array}$ & $\begin{array}{l}\text { Blackbelly } \\
\text { rosefish } \\
(n=54)\end{array}$ & $\begin{array}{c}\text { Blackspot } \\
\text { seabream } \\
(n=55)\end{array}$ \\
\hline \multirow{3}{*}{$\begin{array}{l}\text { All size } \\
\text { classes }\end{array}$} & $\begin{array}{l}\text { Proportion of } \\
\text { occurrence } \\
(\%)\end{array}$ & $16.7 \%$ & $7.7 \%$ & $10.0 \%$ & $3.7 \%$ & $3.6 \%$ \\
\hline & Abundance & $0.22 \pm 0.06$ & $0.12 \pm 0.05$ & $0.16 \pm 0.08$ & $0.06 \pm 0.04$ & $0.04 \pm 0.03$ \\
\hline & Load & $1.3 \pm 0.1$ & $1.6 \pm 0.1$ & $1.6 \pm 0.1$ & $1.5 \pm 0.1$ & $1.0 \pm 0.0$ \\
\hline \multirow{3}{*}{$\begin{array}{c}0.02-1 \\
\text { mm }\end{array}$} & $\begin{array}{l}\text { Proportion of } \\
\text { occurrence } \\
(\%)\end{array}$ & $8.8 \%$ & $5.1 \%$ & $6.0 \%$ & $3.7 \%$ & $3.6 \%$ \\
\hline & Abundance & $0.13 \pm 0.05$ & $0.09 \pm 0.04$ & $0.08 \pm 0.05$ & $0.06 \pm 0.04$ & $0.04 \pm 0.03$ \\
\hline & Load & $1.5 \pm 0.1$ & $1.67 \pm 0.1$ & $1.33 \pm 0.1$ & $1.5 \pm 0.1$ & $1.0 \pm 0.0$ \\
\hline \multirow{3}{*}{$1-5 \mathrm{~mm}$} & $\begin{array}{l}\text { Proportion of } \\
\text { occurrence } \\
(\%)\end{array}$ & $5.3 \%$ & $3.4 \%$ & $2.0 \%$ & $0.0 \%$ & $0.0 \%$ \\
\hline & Abundance & $0.05 \pm 0.02$ & $0.03 \pm 0.02$ & $0.02 \pm 0.02$ & - & - \\
\hline & Load & $1.0 \pm 0.0$ & $1.0 \pm 0.0$ & 1 & - & - \\
\hline \multirow{3}{*}{$>5 \mathrm{~mm}$} & $\begin{array}{l}\text { Proportion of } \\
\text { occurrence } \\
(\%)\end{array}$ & $3.5 \%$ & $0.0 \%$ & $6 \%$ & $0.0 \%$ & $0.0 \%$ \\
\hline & Abundance & $0.04 \pm 0.02$ & - & $0.06 \pm 0.03$ & - & - \\
\hline & Load & $1.0 \pm 0.0$ & - & $1.0 \pm 0.0$ & - & - \\
\hline
\end{tabular}

866

867

868

869

870

871 
Fig. 1. Proportion of individuals containing plastic (\%) and average number of items per 873 habitat and species, including all individuals (plastic abundance) or just the ones found to ingest 874 plastic (plastic load). Asterisk denotes significant differences. There was a significant difference 875 in the plastic abundance between pelagic and benthic fishes sampled (Chi square $=5.95 ; p=0.01$, $876 \mathrm{df}=1)$.
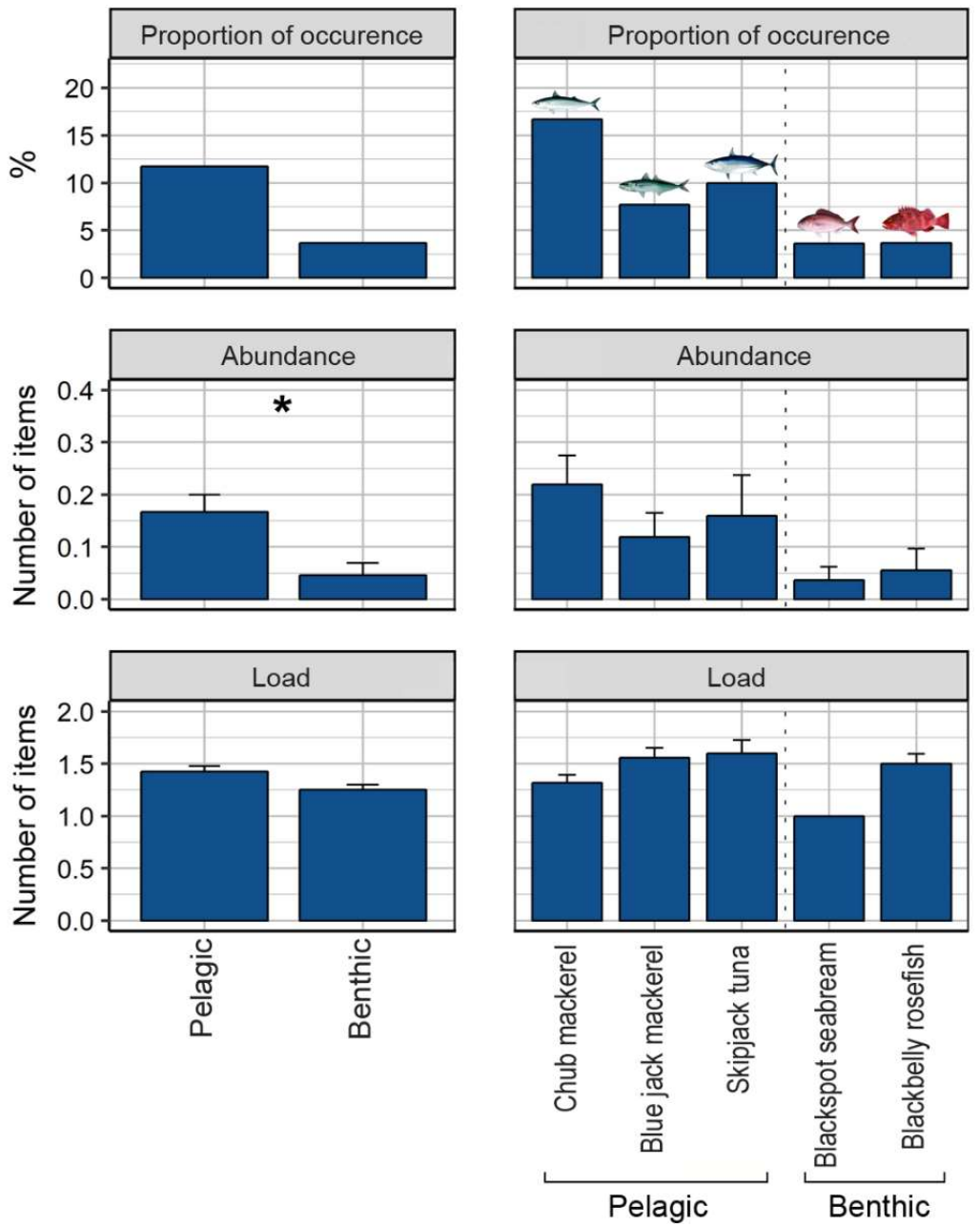
Fig. 2. Boxplot of the length of different plastic shapes recovered from five fish species in the 889 Azores. Number in brackets refers to the number of items recovered. On the right, example images 890 of plastics recovered per shape.
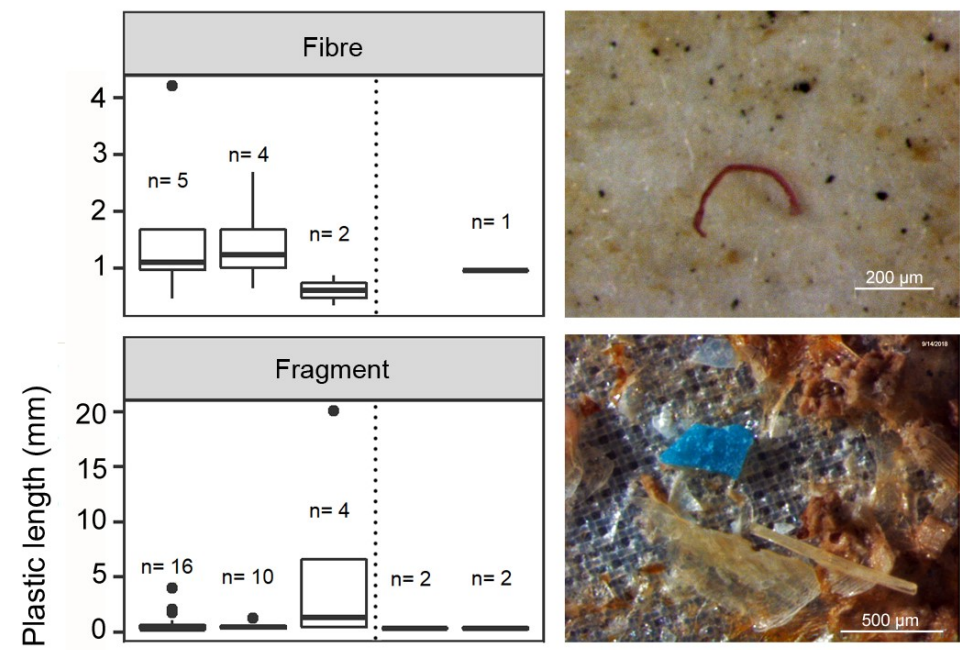

891
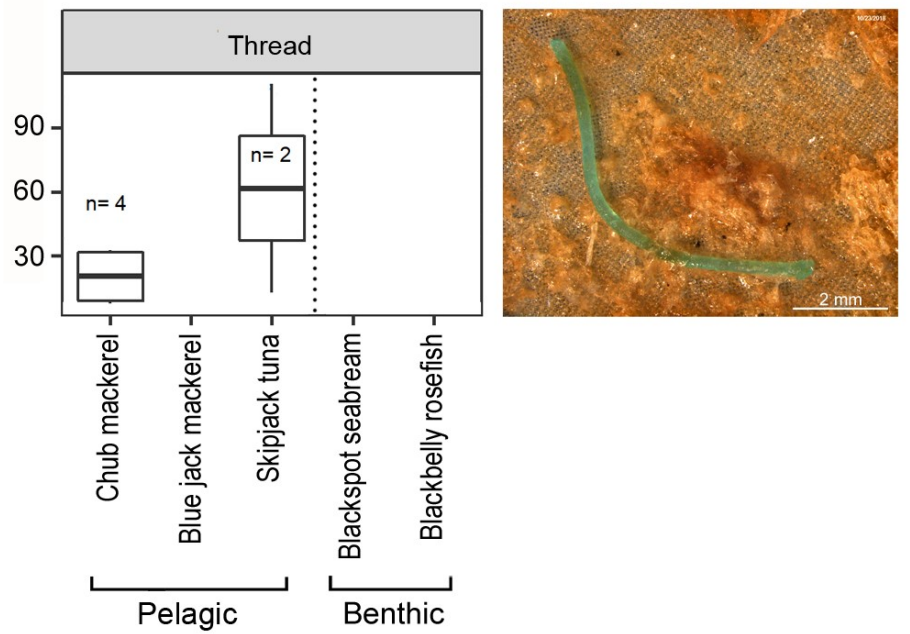
Fig. 3. Correlation between fish length and the size of all plastic items recovered. Different colours represent different fish species.

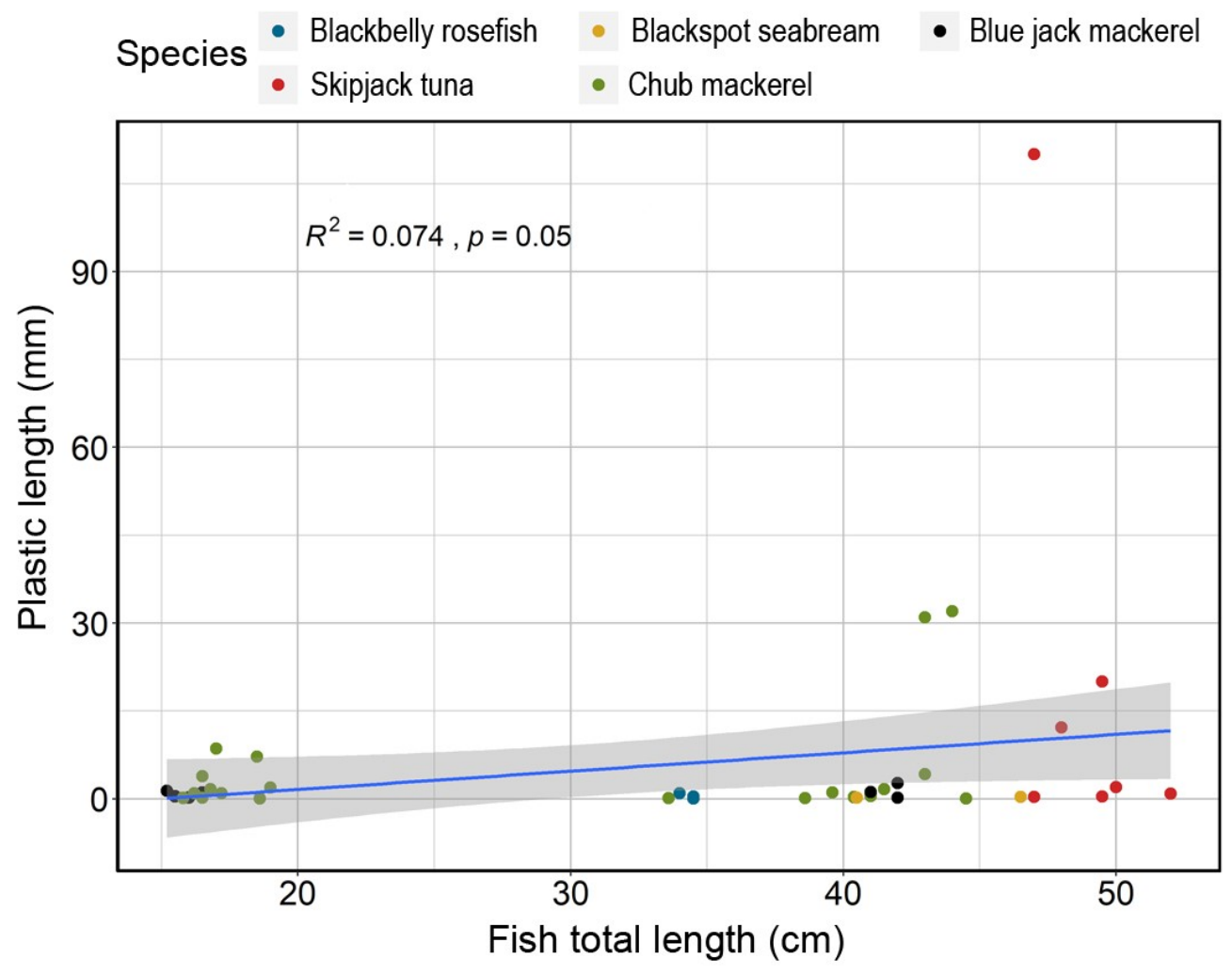


Fig. 4. Colour (A) and polymer (B) composition of the plastic items recovered from the stomach of three pelagic and two deep-water species. Top pie charts are cumulative for each compartment. Polymer identification was obtained with $\mu$-FITR. Polymers identified were polyethylene (PE), polyester (PES), polypropylene (PP), polyethylene terephthalate (PET), polyvinyl chloride (PVC), polyacrylonitrile (PAN), polystyrene (PS), polyamide resin (PA) and polynorbornene 901 (PNR).

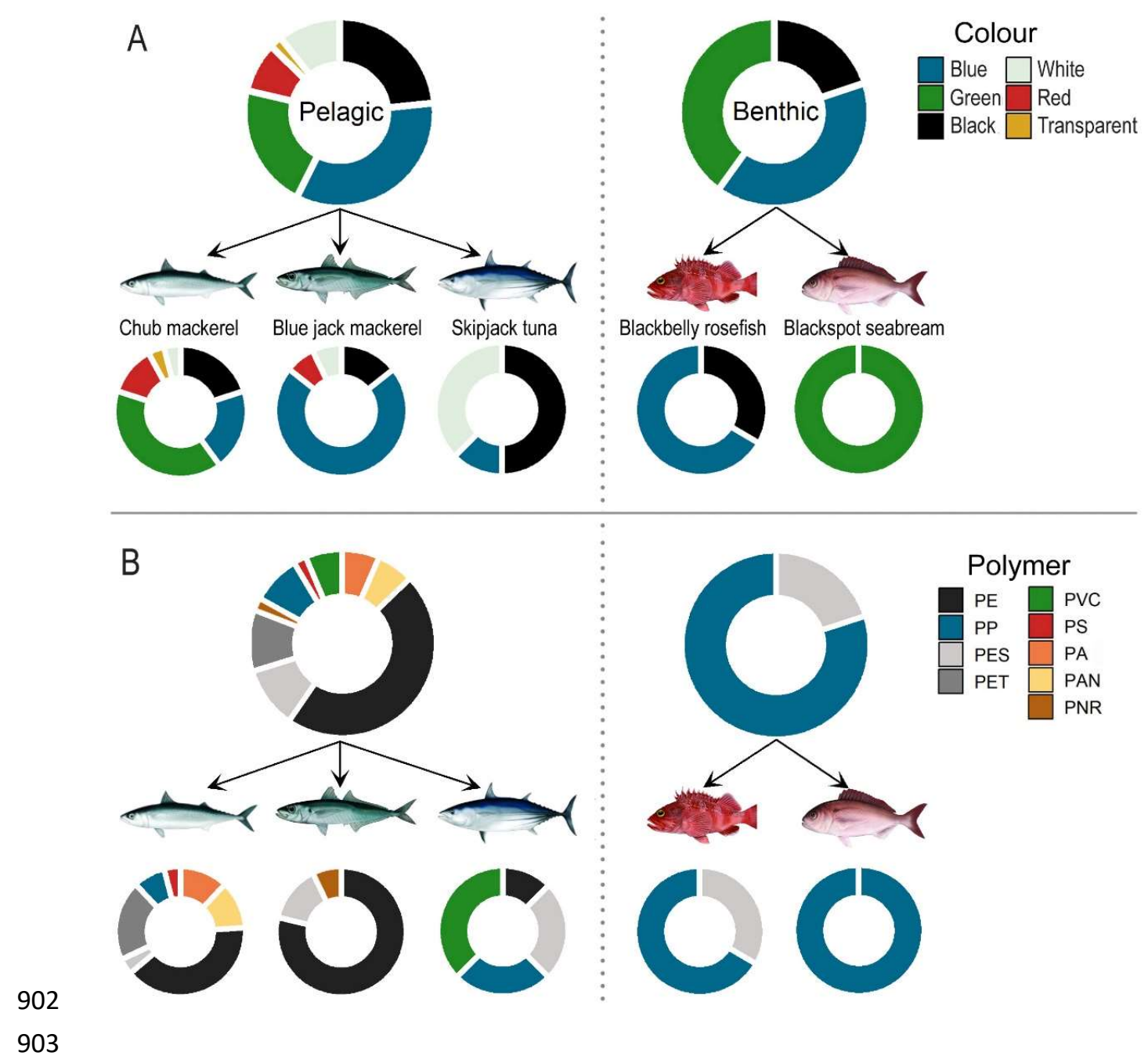

